\title{
Adverse Effects of Allelopathy from Legume Crops and Its Possible Avoidance
}

\author{
Md. Fuad Mondal1,2,3, Md. Asaduzzaman1, Toshiki Asao ${ }^{*}$ \\ ${ }^{1}$ Department of Agriculture, Shimane University, Shimane, Japan \\ ${ }^{2}$ United Graduate School of Agricultural Sciences, Tottori University, Tottori, Japan \\ ${ }^{3}$ Sylhet Agricultural University, Sylhet, Bangladesh \\ Email: fuadentom@yahoo.com, ${ }^{*}$ asao@life.shimane-u.ac.jp
}

Received 10 February 2015; accepted 29 March 2015; published 2 April 2015

Copyright (C) 2015 by authors and Scientific Research Publishing Inc.

This work is licensed under the Creative Commons Attribution International License (CC BY).

http://creativecommons.org/licenses/by/4.0/

(c) (;) Open Access

\begin{abstract}
Plant releases many bioactive chemicals from its various parts such as leaves, stem, root and sometimes decomposed body through different mechanism into its surrounding environment. These bioactive chemicals are often termed as allelochemicals because they interact with the surrounding environment. This interaction is either positive or negative. Effects of allelochemicals to the agricultural and biological ecosystem are well documented. In leguminosae family many species are involved in releasing of allelochemicals. Many researchers found that this allelochemicals have both positive and detrimental effects on the successive legume crops. Legume monoculture is common in many parts of the world where they cause a numbers of ecological and economic problems such as decline in crop yield due to soil sickness, regeneration failure and replant problem. These negative effects of allelochemicals open a great concern on allelopathy research. This article reviews the adverse effects of allelochemicals, their extraction and isolation, mechanism inside the plant body. These all are done to find out the possible selection methods of succeeding crops to avoid the allelopathic effects in the next crop of a monoculture farm field. The main purpose of this article is to highlight the adverse allelopathic effects of legume crops to provide ways for sustainable development in agro-ecosystem.
\end{abstract}

\section{Keywords}

Allelopathy, Allelochemicals, Replant Injury, Succeeding Crops

\section{Introduction}

The family Leguminosae represents the third large plant family with 750 genera and more than 18,000 species Corresponding author.

How to cite this paper: Mondal, Md.F., Asaduzzaman, Md. and Asao, T. (2015) Adverse Effects of Allelopathy from Legume Crops and Its Possible Avoidance. American Journal of Plant Sciences, 6, 804-810. 
having unusual flower structure, podded fruits, and the ability of $88 \%$ of the species examined to date to form nodules with rhizobia [1]. In the context of human importance, it is the second largest family after Graminiae. Grain and forage legume account for $27 \%$ of the world's primary crop production, with grain legumes alone contributing $33 \%$ of the dietary protein nitrogen $(\mathrm{N})$ needs of Humans [2]. Legume seeds contain $20 \%-50 \%$ protein which creates an increasing interest for the utilization of proteins from different legumes. The applications in the food trade are almost limited to protein from legume like soybean Glycine max, whereas other legume plants are less used. Other major grain legumes are pea (Pisumsativum), broad bean (Viciafaba), lentil (Lens culinaris), common bean (Phaseolus vulgaris), Lupinus spp., and chickpea (Cicerarietinum) are generally intercropped with cereals to enhance crop yield, increase nitrogenuse efficiency, and reduce weed infestation and the occurrence of plant disease [3]-[6].

Allelopathy is a phenomenon involving either direct or indirect and either beneficial or adverse effects of a plant (including microorganisms) on another plant through the release of chemicals in the environment [7]-[10]. Among the legume crops many are cultivated as monoculture system that reduces the crop yield with a great extent. The production of legumes declines in replanting conditions due to autotoxicity, a form of intraspecific allelopathy that occurs when a plant species releases chemical substances that inhibit or delay germination and growth of the same plant species [11]-[13]. The phytochemicals of the legume crops are well documented. Plants always produce a complex mixture of secondary metabolites which usually consist of members from different groups, such as polyphenol, terpenoids [14]-[16]. Among the secondary metabolites, some have allelopathic effects in some legumes such as in P. sativum [17], velvet bean (Mucunapruriens) [18], G. max [19]-[21], and C. arietinum [22].

These allelopathic chemical affect the legume plant growth and development and finally yield [20]. Baziramakenga et al. [23] studied the effects of benzoic acid and trans-cinnamic acid on growth of G. max (L.) grown in nutrient solution. The two allelochemicals reduced root and shoot dry biomass of soybean. He found that treated plants with fewer lateral roots and tended to grow more horizontally compared to the untreated plants. Lateral roots were stunted and less flexible. Asao et al. [24] mentioned sweet pea (Lathyrusoduratus L.) shoot fresh weight and dry weight greatly reduced by the release of autotoxic malonic acid, benzoic acids $p$-hydrobenzoic acids and vanillic acids from its roots into the rhizosphere. Assaduzzaman and Asao [25] investigated the autotoxicity of $P$. sativum, $P$. vulgaris, and $V$. faba in hydroponics either with or without activated charcoal (AC) addition. Growth and yield of the three beans were significantly reduced when grown in the culture solution without AC addition. In P. sativum plants the number of pods, pod fresh mass, number of seeds, and seed fresh mass were reduced when plants were grown in non-renewed culture solution without AC. The number of pods plant ${ }^{-1}$ and fresh mass of pods ${ }^{-1}$ plant in P. vulgaris, as well as pod number in $V$. faba, were decreased significantly to $49 \%$ - 67\% without AC addition. Chung and Miller [26] found that alfalfa (Medicago sativa L.) aqueous extracts inhibit its seed germination and seedling growth, and that autotoxicity is concentration dependent and due to water-soluble toxic substances. Batish et al. [27] investigated that caffeic acid significantly suppressed the mung bean (Phaseolus aureus) root growth. Salama et al. [28] investigated the the inhibitory effects of $M$. sativa L. residues on seed germination, nutrient uptake and growth of $V$. faba L. grown in clay and sandy soil. In that research the extract of $M$. sativa strongly inhibited the seed germination index and the plumule and radicle lengths. In field experiments, residues and extracts of $P$. sativum plants suppressed the growth and population of several plant species [29]-[33].

\section{Extraction and Isolation of Allelochemicals}

For the successful identification of different allelochemicals, right extraction and isolation method is predominantly necessary. During autotoxicity plants releases chemicals/allelochemicals to its rhizosphere [13] through various mechanisms. These include root exudation, crop residue decomposition, leachation, volatilization, and pollen spreading in some plants [7] [34]-[38]. So extraction of allelochemicals largely depends on the plant parts which are related to release of allelochemicals or which contain the allelochemicals such as soil or air. Many researchers identified the allelochemicals from legume crops through different techniques and methods using different plant parts and releasing areas. Han et al. [39] identified allelochemicals of G. max from rhizosphere soil extract by gas chromatography-mass spectrometry (GC-MS). Tomita-Yokotani et al. [40] identified allelochemicals from the volatile compounds of $M$. pruriens L. Chung et al. [41] identified the allelochemicals in $M$. sativa from its alfalfa leaves. In this study chemical separation procedures involved a methanol extract of fresh $M$. sa- 
tiva leaves, treatment with activated charcoal, microcrystalline cellulose thin-layer chromatography (MCTLC), and finally separation by column chromatography. The various fractions were examined further by high-performance liquid chromatography (HPLC). Preliminary identification by HPLC was confirmed with GC-MS. Finally it was found that suggested that chlorogenic acid is involved in M. sativa autotoxicity. Kato-Noguchi [17] identified the allelochemicals of $P$. sativum L. by methanol extract of its shoots. Chemical structure of this compound was determined by high-resolution MS, IR and ${ }^{1} \mathrm{H}$ NMR spectral data. Asaduzzaman and Asao [25] identified the allelochemicals of $P$. vulgaris, and $V$. faba by the GC-MS analysis of root exudates by methanol adsorbed in AC form the hydroponic nutrient solution.

\section{Allelochemicals}

During allelopathy plant release chemicals into the surrounding environment termed as allelochemicals. Accumulated allelochemicals create detrimental effects on the growth of next season crop plants [7]. In agro ecosystem legume crops release a great number of allelochemicals. Assaduzzaman and Asao [25] identified benzoic, salicylic, and malonic acidsin the root exudates of $P$. vulgaris and lactic, benzoic, p-hydroxybenzoic, vanillic, adipic, succinic, malic, glycolic, and p-hydroxyphenylacetic acids in $V$. faba. In another study, pisatin in the $P$. sativum shoot was identified by Kato-Noguchi [13]. Asao et al. [24] found malonic acid, benzoic acids $p$-hydrobenzoic acids and vanillic acids in L. oduratus roots extracts. Kato-Noguchi [42] isolated cis, trans-xanthoxin and trans, trans-xanthoxin from the leaves of Puerariathunbergiana through the aqueous methanol extract. Miller [43] reported that various toxic compound potentially involved in autotoxicity are localized in the seed coat, fresh leaves, stems, crowns, dry hay, old roots, and soil residues of M. sativa. Abdul-Rahmanandand Habib [44] in their research found caffeic, chlorogenic, isochlorogenic, $p$-coumaric, $p$-hydroxybenzoic, and ferulic acids in $M$. sativa root exudates and residues. Chung et al. [41] also separated and quantified the allelopathic compounds chlorogenic and salicylic acid from fresh M. sativa, leaves and they suggested that chlorogenic acid is involved in alfalfa autotoxicity. Han et al. [39] extracted organic acids, alcohol, acetone, aldehyde, naphthalene phenyl and furan hydrocarbon from G. max rhizosphere many of which were reported as allelochemicals. Fujii [45] isolated amino acid, L-DOPA from hairy vetch (Vicia villosa) and cyanamide in M. pruriens.

\section{Allelochemical Mechanism}

In general allelochemical plays multiple roles on the physiology of crop plants. It can inhibit plant growth, alter mineral uptake, cause stomatal closure and induce water stress, influence respiration, affect photosynthesis and protein synthesis impair hormone balance and alter enzyme activities. Many researchers have done on the mechanism of allelochemicals in the legume crops [46]-[48]. Cruz et al. [49] investigated the effect of allelochemicals on the $P$. vulgaris root where root tip cells were extruded together and that cell organization was disordered with little cell differentiation Batish et al. [27] reported that the activity proteases in hypocotyl cuttings of $P$. aureus decreased significantly when to the caffeic acid was treated as allelochemical. Baziramakenga et al. [23] studied the effects of benzoic acid and trans-cinnamic acid on growth, mineral composition, and chlorophyll content of soybean G. max grown in nutrient solution. These allelochemical showed negative effects on G. $\max$ by altering ion uptake and transport, and by reducing chlorophyll content. In his research he found that soybean plant reduced the P, K, Mg, Mn, contents in shoots and roots. Patterson et al. [50] reported that caffeic, coumaric, ferulic, cinnamic, and vanillic acid significantly inhibit the growth of soybean G. max by reducing the photosynthetic products and chlorophyll content. In another study Baziramakenga et al. [51] studied the allelochemical effect on the G. max he found that soybean plant growth is affected by the interference of allelochemicals with nucleic acid and protein metabolism. He also found that phosphorus uptake was reduced in G. max by benzoic, cinnamic, vanillic and ferulic acids. Mersie and Singh [52] also mentioned that allelochemicals affect the photosynthesis and protein synthesis in M. pruriens.

\section{Selection Methods of Succeeding Crop in Replant Soil}

Soil sickness and replanting injuries are very common in successive cultures [7] [53] that affect the growth and yield of crops. Replanting problems in continuous cropping is occurred when the chemical interference from previous crop or residue to the same crop or other crop of the next culture. Allelopathic effects from crop resi- 
dues and root exudates have extensively studied in legume such as alfalfa [43] [54]-[56], bean [25]. Generally, leguminous crop such as broad bean, garden pea and snap bean are intensively cultivated in the same farmland continuously without maintaining any crop rotation which hamper the production of bean due to in replanting conditions owing to autotoxicity [11]-[13]. In such a condition suitable succeeding crop with a crop rotation has good control over it. It can limit the soil autotoxicity due to all allelopathy to a greater extend [57]. Assaduzzaman et al. [58] investigated sixty seven cultivars of 42 vegetable crop species from 14 families through seedling growth bioassay using replanting soil for succeeding crops of $V$. faba L., P. sativum L. and P. vulgaris L. replanting soil to suggest their possible succeeding crops. He suggested that most of the cultivars tested can be planted after three beans with fewer to be affected. Among the methods of bioassay he used nutrient solution, direct seed sowing and seedling transplanting in the replanting soil; nutrient solution bioassay has more sensitivity than replanting soil bioassay. However, in the field condition the results of nutrient solution bioassay may not be reproducible. Therefore, he suggested seedling transplanting method as an easy and practical bioassay method for suggesting succeeding crops for a field with replanting problems.

\section{Conclusion}

In the field of the legume allelopathy extensive research has been done and a great numbers of allelochemicals responsible for allelopathy have identified. For sustainable crop production in agriculture, allelopathy research is very important. As allelopathy cause a great loss in legume crops in monoculture system in such a condition, allelopathy research is inevitable. For a successful allelopathy research knowledge on plant physiology and ecology is necessary. This will help to know the synthesis and release of allelochemicals of plants in its surrounding environment. Lack of information on this above two aspects of plants, chemical analysis is worthless. Nowadays by the application of genetic approaches in allelopathy has started which open a new era in allelopathy research. To understand the allelopathic mechanism in legume further studies on the production, role, and fate of allelochemicals in many legume species with the surrounding ecosystem are necessary by using all the mentioned knowledge and techniques. Progress is this research will help in making a crop rotation schedule to improve the crop growth and yield in a sustainable manner.

\section{References}

[1] de Faria, S.M., Lewis, G.P., Sprent, J.I. and Sutherland, J.M. (1989) Occurrence of Nodulation in the Leguminosae. New Phytologist, 111, 607-619. http://dx.doi.org/10.1111/j.1469-8137.1989.tb02354.x

[2] Vance, C.P., Graham, P.H. and Allan, D.L. (2000) Biological Nitrogen Fixation. Phosphorus: A Critical Future Need. In: Pedrosa, F.O., Hungria, M., Yates, M.G., Newton, W.E., Eds., Nitrogen Fixation: From Molecules to Crop Productivity. Kluwer Academic Publishers, Dordrecht, 506-514.

[3] Willey, R.W. (1979) Intercropping-Its Importance and Research Needs. Competitions and Yield Advantages. Field Crop Abstracts, 32, 1-10.

[4] Jensen, E.S. (1996) Grain Yield, Symbiotic N2 Fixation and Interspecific Competition for Inorganic N in Pea-Barley Intercrops. Plant and Soil, 182, 25-38. http://dx.doi.org/10.1007/BF00010992

[5] Hauggaard-Nielsen, H., Ambus, P. and Jensen, E.S. (2001) Temporal and Spatial Root Distribution and Competition for Nitrogen in Pea-Barley Intercropping-A Field Study Employing 32P Methodology. Plant and Soil, 236, 63-74. http://dx.doi.org/10.1023/A:1011909414400

[6] Hauggaard-Nielsen, H., Jornsgaard, J., Kinane, J. and Jensen, E.S. (2008) Grain Legumecereal Intercropping: The Practical Application of Diversity, Competition and Facilitation in Arable and Organic Cropping Systems. Renewable Agriculture and Food Systems, 23, 3-12. http://dx.doi.org/10.1017/S1742170507002025

[7] Rice, E.L. (1984) Allelopathy. 2nd Edition, Academic Press, Orlando, 422.

[8] Bertin, C., Weston, L.A. and Kaur, H. (2008) Allelopathic Crop Development: Molecular and Traditional Plant Breeding Approaches. In: Janick, J., Ed., Plant Breeding Reviews, John Wiley \& Sons, Inc., Hoboken, 231-258. http://dx.doi.org/10.1002/9780470380130.ch4

[9] Kruse, M., Strandberg, M. and Strandberg, B. (2000) Ecological Effects of Allelopathic Plants. A Review, Department of Terrestrial Ecology, Silkeborg, Denmark, Rep. No. 315.

[10] Seigler, D.S. (1996) Chemistry and Mechanisms of Allelopathic Interactions. Agronomy Journal, 88, 876-885. http://dx.doi.org/10.2134/agronj1996.00021962003600060006x

[11] Putnam, A.R. (1985) Allelopathic Research in Agriculture: Past Highlights and Potential. In: Thompson, A.C., Ed., 
The Chemistry of Allelopathy: Biochemical Interactions among Plants, American Chemical Society, Washington DC, 1-8. http://dx.doi.org/10.1021/bk-1985-0268.ch001

[12] Miller, D.A. (1996) Allelopathy in Forage Crop Systems. Agronomy Journal, 88, 854-859. http://dx.doi.org/10.2134/agronj1996.00021962003600060003x

[13] Singh, H.P., Batish, D.R. and Kohli, R.K. (1999) Autotoxicity: Concept, Organisms and Ecological Significance. Critical Reviews in Plant Sciences, 18, 757-772. http://dx.doi.org/10.1080/07352689991309478

[14] Wink, M. and Mohamed, G.I.A. (2003) Evolution of Chemical Defense Traits in the Leguminosae: Mapping of Distribution Patterns of Secondary Metabolites on a Molecular Phylogeny Inferred from Nucleotide Sequences of the $r b c \mathrm{~L}$ Gene. Biochemical Systematics and Ecology, 31, 897-917. http://dx.doi.org/10.1016/S0305-1978(03)00085-1

[15] Wink, M. (2008) Evolutionary Advantage and Molecular Modes of Action of Multicomponent Mixtures Used in Phytomedicine. Current Drug Metabolism, 9, 996-1009. http://dx.doi.org/10.2174/138920008786927794

[16] Wink, M. (2013) Evolution of Secondary Metabolites in Legumes (Fabaceae). South African Journal of Botany, 89, 164-175. http://dx.doi.org/10.1016/j.sajb.2013.06.006

[17] Kato-Noguchi, H. (2003) Isolation and Identification of an Allelopathic Substance in Pisumsativum. Phytochemistry, 62, 1141-1144. http://dx.doi.org/10.1016/S0031-9422(02)00673-8

[18] Fujii, Y., Shibuya, T. and Usami, Y. (1991) Allelopathic Effect of Mucuna pruriens on the Appearance of Weeds. Weed Research in Japan, 36, 43-49. (In Japanese with English Summary)

[19] Huber, D.M. and Abney, T.S. (1986) Soybean Allelopathy and Subsequent Cropping. Journal of Agronomy and Crop Science, 157, 73-78. http://dx.doi.org/10.1111/j.1439-037X.1986.tb00050.X

[20] Xiao, C.L., Zheng, J.H., Zou, L.Y., Sun, Y., Zhou, Y.H. and Yu, J.Q. (2006) Autotoxic Effects of Root Exudates of Soybean. Allelopathy Journal, 18, 121-127.

[21] Yan, F. and Yang, Z. (2008) Allelochemicals in Pre-Cowing Soils of Continuous Soybean Cropping and Their Autointoxication. In: Zeng, R.S., Mallik, A.U. and Luo, S.M., Eds., Allelopathy in Sustainable Agriculture and Forestry, Springer, New York, 271-281. http://dx.doi.org/10.1007/978-0-387-77337-7 14

[22] Yasmin, S., Saleem, B. and Irshad, A. (1999) Allelopathic Effects of Aqueous Extract of Chickpea (Cicer arietinum) and Wheat (Triticum aestivum L.) on Each Other's Growth and Quality. International Journal of Agriculture and Biology, 1, 110-111.

[23] Baziramakenga, R., Simard, R.R. and Leroux, G.D. (1994) Effects of Benzoic and Cinnamic Acids on Growth, Mineral Composition and Chlorophyll Content of Soybean Roots. Journal of Chemical Ecology, 20, 2821-2833. http://dx.doi.org/10.1007/BF02098391

[24] Asao, T., Kitazawa, H., Ushio, K., Sueda, Y., Ban, T. and Pramanik, M.H.R. (2007) Autotoxicity in Some Ornamentals with the Means to Overcome it. HortScience, 42, 1346-1350.

[25] Asaduzzaman, M. and Asao, T. (2012). Autotoxicity in Beans and Their Allelochemicals. Scientia Horticulturae, 134, 26-31. http://dx.doi.org/10.1016/j.scienta.2011.11.035

[26] Chung, I.M. and Miller, D.A. (1995) Effect of Alfalfa Plant and Soil Extracts on Generation and Seedling Growth. Agronomy Journal, 87, 762-767. http://dx.doi.org/10.2134/agronj1995.00021962008700040025x

[27] Batish, D.R., Singh, H.P., Kaur, S., Kohli, R.K. and Yadav, S.S. (2008) Caffeic Acid Affects Early Growth, and Morphogenetic Response of Hypocotyl Cuttings of Mung Bean (Phaseolus aureus). Journal of Plant Physiology, 165, 297305. http://dx.doi.org/10.1016/j.jplph.2007.05.003

[28] Salama, M., Abdelaziz, H.A. and El-Dien, M.H.Z. (2014) Effect of Soil Type on the Allelotoxic Activity of Medicago sativa L. Residues in Vicia faba L. Agroecosystems. Journal of Taibah University for Science, 8, 84-89. http://dx.doi.org/10.1016/j.jtusci.2014.01.001

[29] Cochran, V.L., Elliott, L.F. and Papendick, R.I. (1977) The Production of Phytotoxins from Surface Crop Residues. Soil Science Society of America Journal, 41, 903-908. http://dx.doi.org/10.2136/sssaj1977.03615995004100050018x

[30] Purvis, C.E. (1990) Differential Response of Wheat to Retained Crop Stubbles. I. Effects of Stubble Type and Degree of Decomposition. Australian Journal of Agricultural Research, 41, 225-242. http://dx.doi.org/10.1071/AR9900225

[31] Schenk, S.U. and Werner, D. (1991) $\beta$-(3-Isoxazolin-5-on-2-yl)-Alanine from Pisum: Allelopathic Properties and Antimycotic Bioassay. Phytochemistry, 30, 467-470. http://dx.doi.org/10.1016/0031-9422(91)83706-Q

[32] Tsuchiya, K. and Ohno, Y. (1992) Analysis of Allelopathy in Vegetable Cultivation. I. Possibility of Occurrence of Allelopathy in Vegetable Cultivation. Bulletin of the National Research Institute of Vegetables Ornamental Plants and Tea Series A, 5, 37-44.

[33] Akemo, M.C., Regnier, E.E. and Bennett, M.A. (2000) Weed Suppression in Spring-Sown Rye (Secale cereale)-Pea (Pisum sativum) Cover Crop Mixes. Weed Technology, 14, 545-549. http://dx.doi.org/10.1614/0890-037X(2000)014[0545:WSISSR]2.0.CO;2 
[34] Tang, C.S. and Young, C.C. (1982) Collection and Identification of Allelopathic Compounds from the Undisturbed Root System of Bigalta Limpograss (Hemarthria altissima). Plant Physiology, 69, 155-160. http://dx.doi.org/10.1104/pp.69.1.155

[35] Putnam, A.R. (1985) Weed Allelopathy. In: Duke, S.O., Ed., Weed Physiology Volume 1: Reproduction and Ecophysiology, CRC Press, Boca Raton, 131-155.

[36] Petrova, A.G. (1977) Effect of Phytoncides from Soybean, Gram, Chickpea and Bean on Uptake of Phosphorus by Maize. In: Grodzinsky, A.M., Ed., Interaction of Plants and Microorganisms in Phytocenoses, Naukova Dumka, Kiev, 91-97. (In Russian with English Summary)

[37] Overland, L. (1966) The Role of Allelopathic Substances in the "Smother Crops" Barley. American Journal of Botany, 53, 423-432. http://dx.doi.org/10.2307/2440341

[38] Cruz-Ortega, R., Anaya, A.L. and Romos, L. (1988) Effects of Allelopathic Compounds from Corn Pollen on Respiration and Cell Division of Watermelon. Journal of Chemical Ecology, 14, 71-86. http://dx.doi.org/10.1007/BF01022532

[39] Han, L., Yan, F., Wang, S., Ju, H., Yang, Z. and Yan, J. (2000) Primary Identification of Organic Compounds in Soybean Rhizospheric Soil on Continuous and Alternate Cropping and Their Allelopathy on Soybean Seed Germination. The Journal of Applied Ecology, 11, 582-586.

[40] Tomita-Yokotani, K., Fujii, Y., Yoshida, S., Hashimoto, H. and Yamashita, M. (2003) Volatile Allelopathy in Velvet Bean (Mucuna pruriens [Correction of pruiens] L.) and Gravity. Biological Science in Space, 17, 212-213.

[41] Chung, I.M., Seigler, D., Miller, D.A. and Kyung, S.H. (2000) Autotoxic Compounds from Fresh Alfalfa Leaf Extracts: Identification and Biological Activity. Journal of Chemical Ecology, 26, 315-327. http://dx.doi.org/10.1023/A:1005466200919

[42] Kato-Noguchi, H. (2003) Allelopathic Substances in Pueraria thunbergiana. Phytochemistry, 63, 577-580. http://dx.doi.org/10.1016/S0031-9422(03)00195-X

[43] Miller, D.A. (1983) Allelopathic Effects of Alfalfa. Journal of Chemical Ecology, 9, 1059-1071. http://dx.doi.org/10.1007/BF00982211

[44] Abdul-Rahman, A.A. and Habib, S.A. (1989) Allelopathic Effect of Alfalfa (Medicago sativa L.) on Bladygrass (Imperata cylindrica). Journal of Chemical Ecology, 15, 2289-2300. http://dx.doi.org/10.1007/BF01012082

[45] Fujii, Y. (2003) Allelopathy in the Natural and Agricultural Ecosystems and Isolation of Potent Allelochemicals from Velvet Bean (Mucuna pruriens) and Hairy Vetch (Vicia villosa). Uchu Seibutsu Kagaku, 17, 6-13. http://dx.doi.org/10.2187/bss.17.6

[46] Baziramakenga, R., Leroux, G.D. and Simard, R.R. (1995) Effects of Benzoic and Cinnamic Acids on Membrane Permeability of Soybean Roots. Journal of Chemical Ecology, 21, 1271-1285. http://dx.doi.org/10.1007/BF02027561

[47] Doblinski, P.M.F., Ferrarese, M.L.L., Huber, D.A., Scapim, C.A., Braccini, A.L. and Ferrarese, F.O. (2003) Peroxidase and Lipid Peroxidation of Soybean Roots in Response to $p$-Coumaric and $p$-Hydroxybenzoic Acids. Brazilian Archives of Biology and Technology, 46, 193-198. http://dx.doi.org/10.1590/S1516-89132003000200009

[48] Holappa, L.D. and Blum, U. (1991) Effects of Exogenously Applied Ferulic Acid, a Potential Allelopathic Compound, on Leaf Growth, Water Utilization, and Endogenous Abscisic Acid Levels of Tomato, Cucumber, and Beans. Journal of Chemical Ecology, 17, 865-886. http://dx.doi.org/10.1007/BF01395596

[49] Cruz, O.R., Anaya, A.L. and Hernandez-Bautista, B.E. (1998) Effects of Allelochemical Stress Produced by Sicyos deppei on Seedling Root Ultrastructure of Phaseolous valgaris and Cucubita ficifolia. Journal of Chemical Ecology, 24, 2039-2057. http://dx.doi.org/10.1023/A:1020733625727

[50] Patterson, D.T. (1981) Effects of Allelopathic Chemicals on Growth and Physiological Response of Soybean (Glycine max). Weed Science, 29, 53-58.

[51] Baziramakenga, R., Leroux, G.D., Simard, R.R. and Nadeau, P. (1997) Allelopathic Effects of Phenolic Acids on Nucleic Acid and Protein Levels in Soybean Seedlings. Canadian Journal of Botany, 75, 445-450. http://dx.doi.org/10.1139/b97-047

[52] Mersie, W. and Singh, M. (1993) Phenolic Acids affect Photosynthesis and Protein Synthesis by Isolated Leaf Cells of Velvetleaf. Journal of Chemical Ecology, 19, 1293-1310. http://dx.doi.org/10.1007/BF00984876

[53] Tsuchiya, K. (1990) Problems on Allelopathy in Vegetable Cropping. Agriculture and Horticulture, 65, 9-16. (In Japanese)

[54] Chung, I.M., Seigler, D., Miller, D.A. and Kyung, S.H. (2011) Autotoxic Compounds from Fresh Alfalfa Leaf Extracts: Identification and Biological Activity. Journal of Chemical Ecology, 26, 315-327. http://dx.doi.org/10.1023/A:1005466200919

[55] Nakahisa, K., Tsuzuki, E. and Mitsumizo, T. (1993) Study on the Allelopathy of Alfalfa (Medicago sativa L.): I. Observation of Allelopathy and Survey for Substances Inducing Growth Inhibition. Japanese Journal of Crop Science, 62, 
294-299. http://dx.doi.org/10.1626/jcs.62.294

[56] Nakahisa, K., Tsuzuki, E., Terao, H. and Kosemura, S. (1994) Study on the Allelopathy of Alfalfa (Medicago sativa L.): II. Isolation and Identification of Allelopathic Substances in Alfalfa. Japanese Journal of Crop Science, 63, 278284. http://dx.doi.org/10.1626/jcs.63.278

[57] Batish, D.R., Singh, H.P., Kohli, R.K. and Kaur, S. (2001) Crop Allelopathy and Its Role in Ecological Agriculture. Journal of Crop Production, 4, 121-162. http://dx.doi.org/10.1300/J144v04n02_03

[58] Asaduzzaman, M., Mondal, M.F., Ban, T. and Asao, T. (2013) Selection of Ideal Succeeding Crops after Asparagus, Taro and Beans Replanting Field in Seedling Growth Bioassay. Allelopathy Journal, 32, 1-22. 